\title{
Affirmative action for Brazilian graduate programs: patterns of institutional change
}

\section{Anna Carolina Venturini 1}

${ }^{1}$ Centro Brasileiro de Análise e Planejamento, São Paulo / SP - Brazil

Since 2002, some Brazilian public universities have started adopting affirmative action for admission in graduate programs. This article explains how affirmative action changed admission processes in graduate processes based on (a) an analysis of the selection notices of graduate programs offered in public universities published until January 2018, (b) documents from the programs, and (c) semi-structured interviews with coordinators of graduate programs. The results show that, in most programs, admission processes did not change based on affirmative action. Some programs recognized the obstacles faced by vulnerable groups in accessing graduate programs and altered their procedures. Based on the institutional change typology of Mahoney and Thelen (2010), the analysis points out that more profound change is due to endogenous and incremental processes. The main factor contributing to the modification of the admission criteria is the program's field of knowledge.

Keywords: affirmative action; graduate studies; public university; graduate admission; institutional change.

\section{Ação afirmativa em programas de pós-graduação no Brasil: padrões de mudança institucional}

Desde 2002, programas de pós-graduação de universidades públicas brasileiras começaram a adotar ações afirmativas para seus processos de admissão. Este artigo tem como objetivo explicar como a criação de ações afirmativas resultou na mudança nos processos seletivos de candidatos. Este artigo utilizará (a) uma análise dos editais de seleção de programas de pós-graduação acadêmicos de universidades públicas publicados até janeiro de 2018, (b) documentos disponibilizados pelos programas e (c) entrevistas semiestruturadas com os coordenadores dos programas. Na maioria dos programas, a criação de ação afirmativa não resultou em alteração no processo seletivo. Alguns programas consideraram os obstáculos enfrentados pelos grupos vulneráveis no acesso à pós-graduação e alteraram seus procedimentos. Com base na tipologia de mudança institucional de Mahoney e Thelen (2010), a análise aponta que mudanças mais profundas se devem a processos endógenos e incrementais. $\mathrm{O}$ principal fator que contribuiu para a modificação dos critérios de admissão é a área do conhecimento dos programas. Palavras-chave: ação afirmativa; pós-graduação; universidade pública; admissão na pós-graduação; mudança institucional.

\section{Acción afirmativa en programas de posgrado en Brasil: patrones de cambio institucional}

Desde 2002, los programas de posgrado en las universidades públicas brasileñas han comenzado a adoptar acciones afirmativas para sus procesos de admisión. Este artículo tiene como objetivo explicar cómo la creación de acciones afirmativas resultó en un cambio en los procesos de selección de candidatos. Este artículo utilizará (a) un análisis de los anuncios de selección de programas académicos de posgrado de universidades públicas publicados hasta enero de 2018, (b) documentos puestos a disposición por los programas y (c) entrevistas semiestructuradas con los coordinadores del programa. En la mayoría de los programas, la creación de acciones afirmativas no resultó en un cambio en el proceso de selección. Algunos programas consideraron los obstáculos que enfrentan los grupos vulnerables para acceder a la escuela de posgrado y modificaron sus procedimientos. Basado en el tipo de cambio institucional de Mahoney y Thelen (2010), el análisis señala que los cambios más profundos se deben a procesos endógenos e incrementales. El principal factor que contribuyó a la modificación de los criterios de admisión es el área de conocimiento de los programas.

Palabras clave: acción afirmativa; estudios de posgrado; universidad pública; admisión en el posgrado; cambio institucional. 


\section{ACKNOWLEDGMENTS}

The research was supported by the doctoral grant received from FAPERJ. I would like to thank all those who have read and commented on the preliminary versions of this paper, namely: Prof. João Feres Jr., Prof. Carlos Antonio Costa Ribeiro and Prof. Luiz Augusto Campos (IESP-UERJ); Prof. Ana Claudia Nierdhardt Capella (UNESP); Prof. Jennifer L. Hochschild (Harvard University); Prof. Maria Hermínia Tavares de Almeida and the postdoctoral fellows from IPP-Cebrap; and all the anonymous reviewers.

\section{INTRODUCTION}

In the last decades, the Brazilian system of higher education has undergone several transformations, mainly related to the creation of affirmative action policies and the extension of access to students from public schools, low-income students and self-declared blacks, browns (pardos), and indigenous students in undergraduate courses.

Although usually associated with reserved seats or quotas, affirmative action is broadly conceptualized in the specialized literature ${ }^{1}$ as "any program or initiative, public or private, that aims to confer resources or special rights for members of a specific social group, for a collective good" (Feres, Campos, Daflon \& Venturini, 2018, p. 13). Thus, affirmative action is not restricted to ethnically-racial policies, and includes socially differentiated groups based on gender, sex, caste, residence, the region of origin, religion, disability, socioeconomic status, and other living conditions (Jenkins \& Moses, 2014).

However, although affirmative action has promoted student body diversification in Brazilian universities, the same is not observed in faculty members and graduate researchers. Despite the lack of systematic data on Brazilian public universities' racial makeup ${ }^{2}$, one notes substantial inequalities related to gender, race, and geographical region (Artes, 2016; Rosemberg, 2013).

Some graduate courses (masters and doctorates) of public universities ${ }^{3}$ adopted affirmative action in admission processes. However, such measures suffer from the lack of analysis by the academic literature, with few studies dedicated to the experience of specific graduate programs (De Fiori et al., 2017; Goldman \& Banaggia, 2017; Pereira, 2017; Santos, 2010) and universities (Diniz et al., 2016).

Diversity is a strong argument in favor of affirmative action in graduate schools; a more diverse student body is beneficial to the quality of research, the training of future teachers and researchers, and the improvement of science (Gurin, Dey, Hurtado \& Gurin, 2002; Nature, 2014; Posselt, 2014, 2016). However, the literature on affirmative action for graduate education in Brazil rarely analyzes how decision-makers structured them and how they work in practice.

Hence, this paper seeks to enrich the academic discussion on affirmative action for graduate studies and contribute to the public policy literature on admission processes. It investigates the creation of affirmative action in graduate courses bringing the perspective of institutional change. The typology developed by Mahoney and Thelen (2010) allowed us to classify the changes created by affirmative action generated in the student admission processes.

\footnotetext{
${ }^{1}$ See, for example, the definitions presented by: Kennedy (2015), Sabbagh (2007), and Silva (2006).

${ }^{2}$ There are two main types of higher education institutions in Brazil: (a) the public institutions funded by the Federal, State or Municipal Governments which do not charge tuition; and (b) the private institutions whose students pay tuition fees.

${ }^{3}$ In Brazil, there are two types of graduate courses, stricto sensu courses (masters and doctorates), focused on academic research, and the lato sensu (specializations, MBAs).
} 
The research was based on (a) an analysis of the selection notices of academic graduate programs in public universities published until January 2018, (b) documents made available by the programs and universities (proposals, meeting minutes, resolutions, among others), and (c) semi-structured interviews with some programs' department chairs.

The data collected indicate that in January 2018, there were 737 academic graduate programs with some type of affirmative action, among which $63.9 \%$ apply the quota system exclusively and reserve positions for specific groups (Venturini \& Feres, 2020).

Based on the analysis of the selection notices, we noted that there are different models for the adoption of quotas or additional vacancies in graduate school. The reservation of seats in most graduate programs that adopted affirmative action does not exclude the traditional phases of evaluation from the admissions process. Those policies aim at including individuals from underprivileged groups, but some conventional procedures are likely restrictive (Santos, 2010).

Some programs considered the obstacles faced by vulnerable groups in accessing graduate school during the new policy formulation and altered their admissions processes. Considering that affirmative action and inclusive policies directly affect an institution - graduate schools' rules for application and admission of students - it is relevant to explore institutional changes implemented in these processes.

The first section of the paper presents some data on creating affirmative action in graduate program admissions. The second analyzes the typology of institutional change that supports the discussion. The third section explains the research methodology. The fourth presents the findings and the types of change identified in the graduate programs. The fifth section discusses some of the factors that contribute to the changes. The conclusion discusses the main findings and some paths for future analysis.

\section{AFFIRMATIVE ACTION IN GRADUATE EDUCATION}

Researching graduate programs that adopted affirmative action presents several practical difficulties. Each program establishes its own criteria for selecting students and publishes its own application guides, which aren't available in a unified database. Periodicity is quite variable. ${ }^{4}$ Hence, it was necessary to survey the programs' selection notices.

Since the late 1990s, there's been an incipient debate about diversity regarding access to graduate education. The Universidade do Estado da Bahia (Uneb) was the first institution to establish, in 2002, an affirmative action policy aimed at the entry of blacks and indigenous people into undergraduate and graduate courses. Nevertheless, only after 2012 do more affirmative action proposals begin to emerge at this educational level (Venturini, 2019). The data collected up to January 2018 indicate 737 academic graduate programs with some type of affirmative action.

Some policies stemmed from the decisions of the programs themselves, while others were created to comply with state laws or University Council resolutions, valid for all graduate courses at a given university. Analyzing the way affirmative policies are created is relevant since it allows us to identify the institutions that produced these policies by their own initiative and those forced to do so.

The data collected indicate that only $18.3 \%$ of the programs created measures by their initiative. Graph 1 shows that between 2015 and 2018, the number of policies resulting from university resolutions

\footnotetext{
${ }^{4}$ Some programs have only one annual selection process, while others conduct up to two selections per year.
} 
increased fivefold. This increase was induced by Normative Order MEC No. 13/2016, issued by the Ministry of Education (MEC), which determined that all federal institutions of higher education should send proposals for the inclusion of blacks, browns, indigenous, and people with disabilities in their graduate programs. Many universities considered the Normative mandatory and issued resolutions on the matter (Venturini, 2019).

\section{GRAPH 1 NUMBER OF GRADUATE PROGRAMS ACCORDING TO THE FORMS OF CREATION OF AFFIRMATIVE ACTION (2015-2018)}

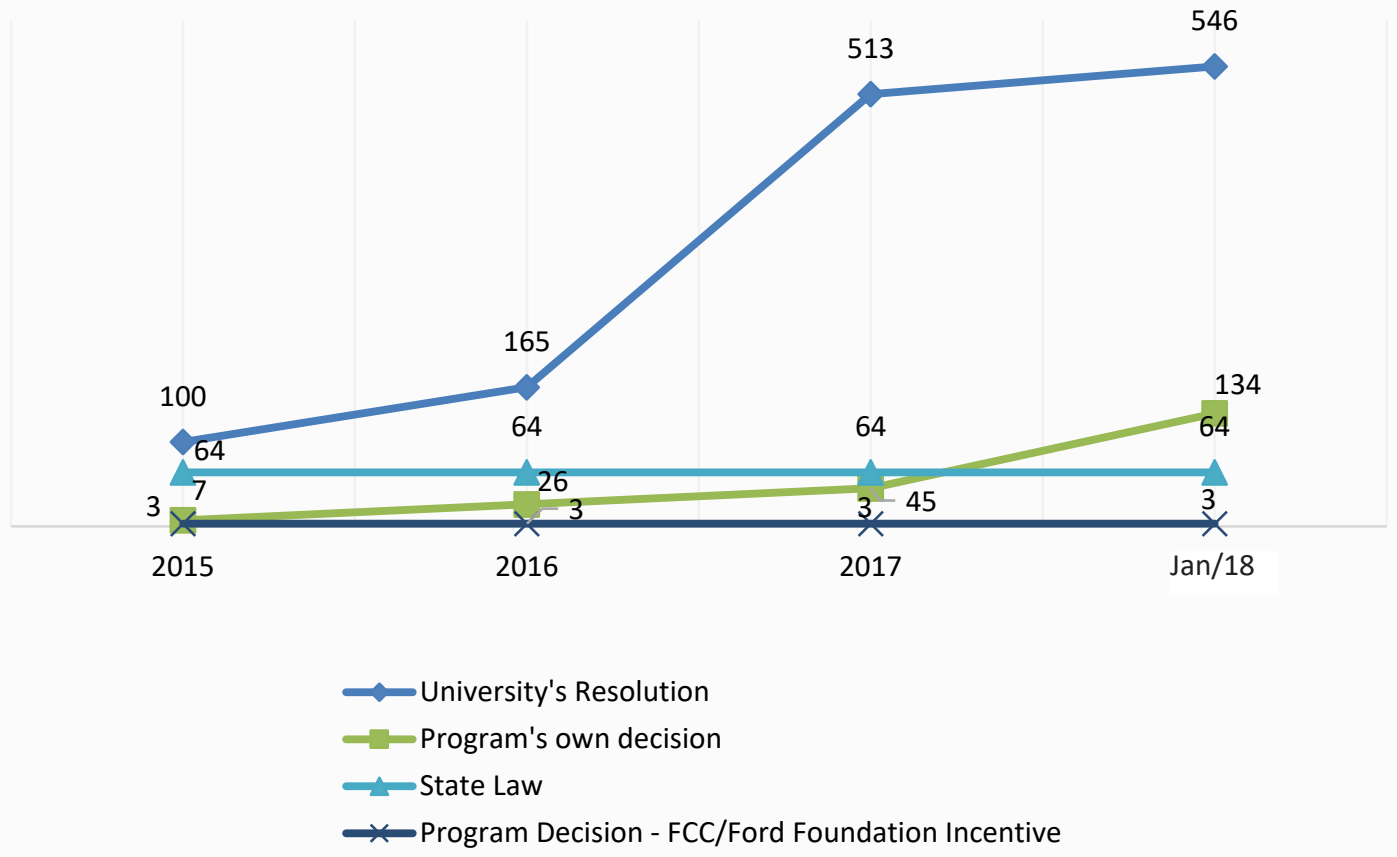

Source: Venturini and Feres (2020).

Another point of discussion about affirmative action is the policies' denomination as "quotas." This type of policy, also known as a seat reservation system, corresponds to allocating a portion of the seats to students belonging to specific groups (Feres et al., 2018, p. 19). Among the 737 graduate programs with affirmative policies, $67.2 \%$ apply the quota system exclusively, followed by those that created additional seats reserved for candidates who meet the requirements. The primary beneficiaries are black (blacks and browns), indigenous people, people with disabilities, quilombolas ${ }^{5}$, transgender, holders of humanitarian visas (refugees), and others (Venturini \& Feres, 2020).

\footnotetext{
${ }^{5}$ A quilombola is an Afro-Brazilian resident of quilombo settlements. The term "quilombo" has a "polysemic character, open, with great empirical variations of occurrence in time and space" (Arruti, 2008, p. 315). According to the Brazilian Association of Anthropology (Associação Brasileira de Antropologia [ABA], 1994), the term "quilombo" designates "black segments in different regions and contexts in Brazil", being "groups that have developed resistance practices in maintaining and reproducing their characteristic ways of life in a given place." They are ethnic groups whose identity is defined by "a common historical reference, built on shared experiences and values." They are not isolated groups. They do not always originate in rebellious movements and collective use of the lands. For more about "quilombos", see: Moura (1972) and Nascimento (1980).
} 
Studies show that although access to the university has been democratized, and there has been a significant increase in diversity in higher education, this varied significantly by careers: areas less valued by the labor market, such as the Humanities and Applied Social Sciences, became more diverse than the so-called "hard" areas (Ribeiro \& Schlegel, 2015). Thus, one of the variables of interest was the distribution of affirmative policies to graduate courses in the different fields of knowledge, according to Capes' (Coordination for the Improvement of Higher-Level Personnel) definition (Venturini \& Feres, 2020).

\section{INSTITUTIONS AND SOURCES OF CHANGE}

The concept of institution is central to approaches that seek to understand the processes of institutional change. There are many definitions of institutions in the literature. This paper uses the definition given by Mahoney and Thelen (2010, p. 4), which treat institutions as "relatively enduring features of political and social life (rules, norms, procedures) that structure behavior and that cannot be changed easily or instantaneously". Therefore, institutions reduce uncertainty by providing a structure for daily life and incentives for political, social, and economic exchange. The authors also agree that institutions are distributive instruments loaded with power implications (Hall, 1986) and sustains that "institutions are fraught with tensions because they inevitably raise resource considerations and invariably have distributional consequences" (Mahoney \& Thelen, 2010, p. 8). In this paper, institutions are considered the rules and procedures that structure admission into graduate programs ${ }^{6}$. The analysis will focus on the changes made to these procedures due to the creation of affirmative action.

Affirmative action affects an institution directly; graduate programs and their admissions processes have the power to influence who will become researchers and Faculty members, a space currently occupied by a relatively homogenous group in ethnic-racial, social, and regional terms (Artes, 2016).

In Brazil, there was no consideration of the asymmetric distribution of opportunities within Brazilian society and the obstacles faced by certain groups to enter graduate education. There is, consequently, a tendency for continuity and maintenance of the same criteria and processes, which are seen as sufficient to achieve the desired outcomes by the actors and to preserve the resources channeled to these programs (Mahoney, 2000; Pierson, 2004).

Like other institutions, graduate programs and their admissions processes have rules that directly affect resource allocation. For example, programs with grades 6 and 7 integrate Capes-Academic Excellence Program (Proex) and receive a budget allocation that can be used for scholarships, resources for investment in laboratories, events, publications, among others. In consequence, the eventual reduction of the grade may impact research funding. Actors that oppose affirmative action argue that they can negatively impact the programs' evaluation and, consequently, the number of research resources (Venturini, 2019). There is much uncertainty concerning these policies, and many actors expressed resistance to change. Thus, understanding the different types of change that have been generated by affirmative action policies is crucial.

\footnotetext{
${ }^{6}$ The discussion in this paper is limited to formal institutions.
} 
The literature sustains that the process of institutional change can be the result of external or internal shocks, as well as sudden or incremental shocks. For a long time, institutionalism, in all its aspects - sociological, rational choice, and historical - was mainly dedicated to processes of abrupt changes brought by external shocks. In order to explain changes, historical institutionalists have, on many occasions, emphasized "critical junctures," understood as periods that open opportunities to the agents to change the development trajectory of a policy or an institution, which results in a new path of development that will then persist for an extended period (Capoccia, 2015; Capoccia \& Kelemen, 2007; Katznelson, 2003).

The analysis of change is also closely related to the notion of path dependence, according to which institutional arrangements established in a particular moment become deep-rooted due to their capacity to shape incentives, worldviews, and resources of actors and groups affected by the institution (Capoccia, 2015, pp. 147-148; Capoccia \& Kelemen, 2007). For Pierson (2004, p. 21), path dependence refers to social processes that exhibit positive feedback, or in other words, to processes in which the benefits of current activities increase throughout the time when compared to other possible options, as the costs of change are high because of the element of uncertainty. Therefore, growing returns explain why actors have powerful incentives to focus on a single alternative and proceed on a particular path (Pierson, 2004, p. 23). That is why, after they are created, institutions are difficult to change, given that, often, a very rigid format has been incorporated into the design of institutions to reduce uncertainty and increase stability (Pierson, 2004, p. 43).

Considering all these challenges to institutional change, an important line of research resorted to a discontinuous model of change. Long periods of stability are periodically disturbed by external shocks that open space to sudden institutional changes, involving, in many cases, the collapse of a set of institutions and their replacement by others (Baumgartner \& Jones, 1993). Thus, "critical junctures" are often attributed to great exogenous shocks, such as wars or economic crises, that act as catalyzers of lasting institutional changes (Pierson, 2004, p. 135).

In the case of affirmative action in graduate programs, it is possible to note the influence of an external element that served as a trigger to creating and diffusing these policies throughout the country: Normative Order MEC No. 13/2016. Although this order only determined that programs should submit proposals, many programs and universities understood that the creation of affirmative action was mandatory and started to develop affirmative action. Thus, although it does not represent an exogenous shock as conceptualized by the literature, the order could be considered an external element that acted as an incentive, influencing the creation of an increasing number of measures in the past years. However, there have been no changes in the traditional criteria for admission in a significant number of cases. As we will show, the data indicate that more significant institutional reforms result from endogenous and incremental processes.

Therefore, the exogenous shock model doesn't appear to be the sole explanation for affirmative action in graduate programs. As indicated by Thelen (2003, p. 209), the exogenous shock model doesn't consider that some institutional arrangements are more resistant to change, even when facing external shocks. This does seem to be the case in graduate programs in Brazil, because, despite the executive order, many graduate programs have not bothered discussing affirmative action in their 
boards and did not modify their admission criteria. In addition to that, even though the executive order has resulted in a sudden increase in affirmative action policies, many of these programs were already going through a process of change since 2002 .

It is then necessary to use a model that comprehends a systematic theory of institutional change and complements the analyses of punctuated equilibrium and path dependence with mechanisms that capture the logic of institutional evolution and endogenous processes of change. Therefore, the research that follows is based on the historical institutionalism theories about institutional change, especially the model developed by Thelen $(2004,2003,2009)$ and others (Hacker, Pierson \& Thelen, 2015; Mahoney \& Thelen, 2010; Streeck \& Thelen, 2005).

In this context, the changes in graduate programs and their admission processes due to affirmative action were analyzed according to the typology, which identifies four types of institutional change: displacement, layering, drift, and conversion.

Displacement occurs when old rules and practices are removed and replaced by new previously unfamiliar models (Mahoney \& Thelen, 2010). This type of change can be abrupt and implicate in an unexpected change with the collapse of institutions and their replacement by new rules. Displacement can also be a gradual and slow process when newly-introduced rules and institutions compete with older rules instead of immediately overthrowing them.

Layering happens through a process of differentiated growth (Streeck \& Thelen, 2005, p. 23), in which minor modifications are introduced and coexist with old practices (Mahoney \& Thelen, 2010 , p. 15). In contrast to displacement, layering doesn't involve the creation of totally new rules and institutions, but, rather, alterations, revisions, and additions to existing regulations, which may result in significant changes in the long term. Mahoney and Thelen (2010, p. 17) understand that layering may result in substantial changes if the amendments alter the logic of institutions to the extent that this "compromises the stable reproduction of the original 'core"'

Drift occurs in situations where the rules remain formally unchanged, but their impact (or effects) changes due to changes in external conditions (Hacker et al., 2015; Mahoney \& Thelen, 2010; Streeck \& Thelen, 2005; Thelen, 2004). Hence, drift occurs when external transformations alter the rules' result without changing the rules themselves (Hacker et al., 2015, p. 184). Conversely, the rules also remain formally unchanged. However, they start to be interpreted and promulgated in different ways, which makes the existing institutions be redirected to new purposes, transforming their functions and the roles they play (Hacker et al., 2015, pp. 185-186; Mahoney \& Thelen, 2010; Thelen, 2003, p. 228; Thelen, 2004, p. 36).

The typology allowed us to identify the different types of change that happen in graduate programs and their admission processes through the creation of affirmative action. Therefore, the analysis that follows will focus on the types of change identified in graduate admissions and some of the institutional characteristics that contributed to the modifications. One of the hypotheses this research intended to validate was that the program's area of knowledge influences the degree of change. Studies show that at the undergraduate level, some areas (Humanities and Applied Social Sciences) became more diverse than the so-called "hard" areas (Ribeiro \& Schlegel, 2015). 


\section{METHODOLOGICAL NOTES}

Considering that there are 4,175 stricto sensu graduate programs in Brazil accredited by Capes, we restricted the universe to academic graduate programs (master's and doctorates). We chose to analyze only public universities, since these "constitute the main institutional support for research and the training of researchers" (Durham, 1998, p. 1). Finally, we limited the analysis to programs accredited and recommended by Capes in the latest four-year assessment, those with grades 3 to $7 .^{7}$ The criteria allowed the representative data analysis of 2,763 graduate programs, which correspond to $66.2 \%$ of programs in the country. This selection enabled us to examine a very significant portion of Brazilian graduate education and the institutions that concentrate most of the qualified academic research and education.

Using the programs listed on Capes' last four-year evaluation report, we accessed each program's website to search for the selection notices. If notices were not located on the websites, we contacted the programs by e-mail or telephone. Those who still did not respond were coded as having no affirmative action, since it was not possible to analyze their selection notices. All application guides were analyzed, and those containing affirmative action were separated and codified as per the following characteristics: university; program code according to Capes data; area of knowledge; type of affirmative action; beneficiaries; Capes grade; state; and region. The chosen variables aimed to establish the policy's main characteristics.

Based on the typology of change mentioned above, we decided to develop a variable that would allow us to identify the number of changes that the programs made in their selection process to make it more inclusive to specific groups. In order to do this, we had to analyze the programs with affirmative action and their admission rules. In addition to the selection notices, we also analyzed documents like affirmative action proposals, meeting minutes, and internal resolutions, among others.

To identify and classify different types of change in admission policies, the first step of the research consisted in separating the selection notices of 137 graduate programs that created affirmative action on their own initiative, disregarding those made by legal determination or university council resolutions. The policy creation analysis allows us to identify if the programs created them independently or were forced to do so. The change initiative's origin indicates a real desire for diversity policies and changes in the procedures. The 137 programs that created policies independently represent $18.3 \%$ of all affirmative action programs until January 2018.

Subsequently, all selection guides of the 137 programs were codified using NVivo software to identify the main stages and admission criteria. This resulted in a list of the main stages: type of seats, type of application guide, score minimums (nota de corte) ${ }^{8}$, exams, proficiency in foreign languages, evaluation of $\mathrm{CV}$, research project, interview, recommendation letters, and acceptance of advisor (Box 1).

The third stage consisted in creating codes to identify the type of amendments related to affirmative

\footnotetext{
7 "Programs that receive grades 1 and 2 have their functioning authorizations and recognition of the master's and/or doctoral courses canceled" (Capes, 2019, own translation). Retrieved from http://www.capes.gov.br/perguntas-frequentes

${ }^{8}$ Score minimums refer to the minimum scores that an applicant must achieve to be approved in each stage or for final approval.
} 
action policies. For this, the 137 application guides were analyzed to verify features that were subject to modifications in favor of certain groups or remained the same and applicable to all candidates. Box 1 below describes the codes that were created and applied to the NVivo software.

CHARACTERISTICS OF THE ADMISSION PROCESSES AND TYPES OF CHANGE

\begin{tabular}{|c|c|c|}
\hline Stages of the Admission Process & Code & Type of change \\
\hline \multirow[t]{2}{*}{ Seats } & 1 & Larger poll \\
\hline & 2 & Reserved for certain groups \\
\hline \multirow[t]{4}{*}{ Application guide } & 1 & Single process \\
\hline & 2 & Separate for affirmative action \\
\hline & 3 & Separate for indigenous \\
\hline & 4 & Separate for other groups \\
\hline \multirow[t]{3}{*}{ Score Minimums } & 0 & Non-applicable \\
\hline & 1 & Same for all \\
\hline & 2 & Modified for certain groups \\
\hline \multirow[t]{3}{*}{ Written exam } & 0 & Non-applicable5 \\
\hline & 1 & Same for all \\
\hline & 2 & Modified for certain groups \\
\hline \multirow[t]{3}{*}{ Oral exam } & 0 & Non-applicable \\
\hline & 1 & Same for all \\
\hline & 2 & Modified for certain groups \\
\hline \multirow[t]{3}{*}{ Proficiency in a foreign language } & 0 & Non-applicable \\
\hline & 1 & Same for all \\
\hline & 2 & Modified for certain groups \\
\hline \multirow[t]{3}{*}{ Evaluation of CV and publication } & 0 & Non-applicable \\
\hline & 1 & Same for all \\
\hline & 2 & Modified for certain groups \\
\hline \multirow[t]{3}{*}{ Research project } & 0 & Non-applicable \\
\hline & 1 & Same for all \\
\hline & 2 & Modified for certain groups \\
\hline \multirow[t]{3}{*}{ Oral defense of the project } & 0 & Non-applicable \\
\hline & 1 & Same for all \\
\hline & 2 & Modified for certain groups \\
\hline
\end{tabular}




\begin{tabular}{l|c|l}
\hline Stages of the Admission Process & Code & \multicolumn{1}{c}{ Type of change } \\
\hline Interview & 0 & Non-applicable \\
& 1 & Same for all \\
\hline Recommendation Letter & 2 & Modified for certain groups \\
& 0 & Non-applicable \\
\hline Acceptance of advisor & 1 & Same for all \\
& 2 & Modified for certain groups \\
& 0 & Non-applicable \\
& 1 & Same for all \\
& 2 & Modified for certain groups
\end{tabular}

Source: Elaborated by the author.

The last step consisted in creating a dataset with (a) the number of characteristics of the admission process for each program and (b) the codes of Box 1 that applied to each step of the process. Then, the degree of change (DC) was established based on the ratio between the number of changes $(m)$ and the sum of characteristics of the admission process (c), according to the formula below:

$$
D C=\frac{m}{c}=\frac{m_{1}+m_{2}+m_{3}+m_{n}}{c_{1}+c_{2}+c_{3}+c_{n}}
$$

The data about the degree of change of 137 programs with affirmative action was transformed into a scale ranging from 0.1 (lowest) to 1 (highest).

The paper also uses data from semi-structured interviews. Although a lot of information is available in public documents, a purely documentary analysis did not prove sufficient for a more in-depth analysis of these measures and change patterns. Therefore, in-depth interviews were carried out with selected actors from some programs (Harvey, 2011; Hochschild, 2005; Kapiszewski, 2015; Mosley, 2013).

Seven department chairs of programs that approved affirmative action were interviewed for this paper. The first step in selecting the interviewees involved dividing the programs by area of knowledge 9 This variable was essential to understand if there were differences in change patterns. The random sampling method was then applied to select a program from each of the nine fields of knowledge (Goldstein, 2002; Kapiszewski, 2015; Lynch, 2013). Subsequently, e-mail requests were sent to the selected programs. The Engineering area did not have a program with affirmative action created on its own initiative. In the field of Exact and Earth Sciences, no program responded to requests for an interview. We acknowledge that the interview sample is not representative of the programs

\footnotetext{
${ }^{9}$ Capes divides programs into nine major fields: Exact and Earth Sciences, Biological Sciences, Engineering, Health Sciences, Agricultural Sciences, Applied Social Sciences, Humanities, Linguistics, Literature and Arts, and Multidisciplinary.
} 
that decided to create affirmative action themselves. Nevertheless, the in-depth interviews allowed us to explore a topic that is still uncommon in the literature and a gain better understanding of the decision-making process.

\section{BOX 2 LIST AND CODING OF PROGRAM INTERVIEWEES}

\begin{tabular}{llcc} 
& \multicolumn{2}{c}{ Programs that have created affirmative action on their initiative } & \\
Interviewee Code & \multicolumn{1}{c}{ Knowledge Area } & Region & Capes grade \\
\hline Interviewee AG & Agricultural Sciences & North & 4 \\
Interviewee Bio & Biological Sciences & Southeast & 6 \\
Interviewee HS & Health Sciences & Southeast & 4 \\
Interviewee H & Humanities & South & 6 \\
Interviewee SA & Applied Social Sciences & Southeast & 6 \\
Interviewee LLA & Linguistics, Literature, and Arts & South & 5 \\
Interviewee M & Multidisciplinary & North & 3
\end{tabular}

Source: Elaborated by the author.

The semi-structured interviews' basic script contained 15 questions about policy formulation and the decision-making processes as well as barriers faced by the beneficiary groups and proposals to amend the admission criteria. We tested the script with academics and public administrators before their use in the field (Leech, 2002; Mosley, 2013). The interviews lasted around 1 hour each. All were transcribed and coded into categories such as barriers to access, amendments of admission criteria, resistance, arguments in favor and against, and motives to change (Aberbach \& Rockman, 2002; Kurasaki, 2000) in the NVivo software. The qualitative part of the research was submitted to the approval of the Rio de Janeiro State University (UERJ) Ethics Committee through the Brazil Platform $\left(\mathrm{CAAE}^{10} \mathrm{n}^{\circ}{ }^{6}\right.$ 64214716.6.0000.5282) and obtained a favorable opinion on March 17, 2017 ${ }^{11}$. All interviewees were informed of the research purposes and risks. All participants signed a Term of Informed Consent (TCLE).

\section{FINDINGS}

This section aims to identify the different types of change that happened in graduate admission processes by creating affirmative action. It is essential to classify the kinds of change and develop analyses capable of identifying the sources of variation.

In most programs, affirmative action quotas do not exclude the traditional stages of the admission process (Box 1). However, if these policies aim to include individuals from

\footnotetext{
${ }^{10}$ Certificate of Presentation for Ethical Appreciation

${ }^{11}$ Opinion No. 1,970,173.
} 
underprivileged groups, some of these procedures have a high potential for exclusion and affect the policies' goals. Some argue that low-income and indigenous students, for instance, are often eliminated in the initial stages of the process, mainly due to the requirement of proficiency in foreign languages. Santos (2010) approaches this issue when discussing creating a research field in Human Rights at the University of São Paulo Law School (USP) and quotas. The program's selection notices establish that the first stage of the admission process consists of a qualifying exam attesting to the candidate's proficiency in foreign languages. According to Santos (2010), after creating the new field and implementing quotas, 61 students applied to the reserved seats, but only four passed the language exam.

The data collected shows that some graduate programs considered the obstacles to access encountered by many groups when formulating affirmative action policies. The proposal presented to the program in Social Anthropology of the National Museum - Federal University of Rio de Janeiro (PPGAS-MN/UFRJ), for example, highlights that the barriers faced by blacks would not be removed simply through the creation of quotas or additional seats (Venturini, 2017). Hence, the adoption of other measures would be necessary, such as, for instance, reducting score minimums. Therefore, it is crucial to understand what types of change have been promoted by creating affirmative action in the programs' admission processes.

Analyzing the degree of change distribution, we notice that $89.1 \%$ of the 137 programs made changes in less than $40 \%$ of the characteristics of their admissions processes. The proportion of the programs that underwent more significant changes is low.

\section{GRAPH 2 RATIO OF THE DEGREE OF CHANGE ( $=137)$}

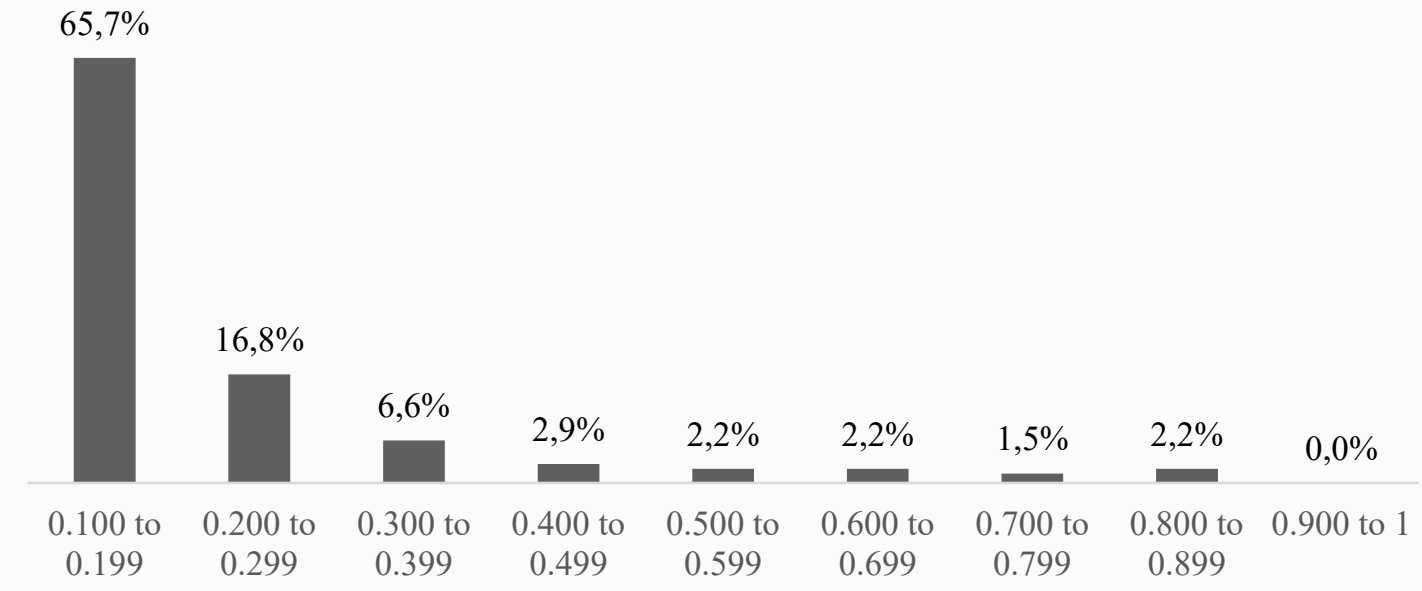

Source: Elaborated by the author. 
Based on the collected data, there are two main forms of institutional change in graduate programs: layering and displacement.

\subsection{Cases of change through layering}

The modality of change through layering happens when the traditional admission process is not entirely modified to adapt to particular groups. However, it is sustained in coexistence with new rules of an inclusive nature. Programs that altered between $10 \%$ and $69 \%$ of the admission criteria in favor of certain groups were considered layering, meaning those that present a degree of change equal or superior to 0.1 and inferior to 0.7 .

Among graduate programs that independently approved affirmative action, we identified programs with a low degree of change (degrees 0.1 to 0.19 ) and intermediate degrees of change (degrees 0.2 to 0.69 ).

The programs with low degrees of change are those in which the only difference in the admission was the creation of quotas or additional seats for specific groups. In other words, no changes were made in other stages, and those applying to the reserved seats are submitted to the same rules applicable to other candidates.

The significant number of programs within this particular range (65.7\%) is related to the fact that most programs that created affirmative action adopted a model of quotas mostly disseminated by undergraduate admissions ${ }^{12}$ and public servants' selection process ${ }^{13}$. The benefits and positive results, especially in undergraduate courses (Senkevics \& Mello, 2019), offer actors strong incentives to use the same modality. Thinking about other solutions explicitly designed for graduate programs would demand resources, time, and increase uncertainty (Pierson, 2004, pp. 21-23). Interviewee HS1, whose program is within this range, reported that those responsible for preparing the proposal in his program sought to understand how other health science programs were implementing affirmative action. However, the program chose to establish different quota percentages than those adopted by the models.

In cases with intermediate degrees of change, the modifications vary. Beyond the creation of quotas, some programs reduced the score minimums for applicants in specific groups. That is the case of the program in Social History at the Federal University of Rio de Janeiro (UFRJ), in which the selection notices establish that blacks, indigenous people and candidates with disabilities have a lower minimum score of 6 points (instead of 7).

Other programs adjusted the criteria to attest proficiency in languages, which they consider necessary for many reasons. The interviewees' first reason is related to the fact that many books and articles have not been translated into Portuguese yet. Thus, proficiency would be relevant to the quantity and the quality of the literature students can absorb. Moreover, Capes encourages programs to promote their internationalization through publication in foreign journals,

\footnotetext{
${ }^{12}$ Federal Law 12,711/2012. Retrieved from http://www.planalto.gov.br/ccivil_03/_ato2011-2014/2012/lei/112711.htm

${ }^{13}$ Federal Law 12,990/2014. Retrieved from http://www.planalto.gov.br/ccivil_03/_ato2011-2014/2014/lei/112990.htm
} 
participation in international conferences, and research periods abroad. Thus, programs have strong incentives to require proficiency in foreign languages - usually one language for master's and two for doctorates.

Nevertheless, some programs decided to change the rules. In some cases, the candidates applying through affirmative action are dismissed from taking foreign language exams. The group that benefited the most from this decision was indigenous candidates, who are exempted from having to prove proficiency in a foreign language, seeing as Portuguese could be considered their foreign language, since they may have their native languages as first languages. Interviewee $\mathrm{H}$ mentioned that the program changed the rules, so that "both indigenous and deaf students have Portuguese as an additional language. So, they take a test, as if it were a proficiency test, but it's called an additional language [...], and Portuguese would be considered a second language."

Among the inclusive measures related to language proficiency that have been applied to all candidates (whether or not they opt for affirmative action), we can highlight: the concession of an extended deadline to attest proficiency; the possibility of taking a new test after an established period; and the approval in a foreign language exam as part of a classifying stage instead of an eliminatory on $e^{14}$. In some programs, like the Interviewee SA program, proficiency in a foreign language is only a requirement for the thesis or dissertation defense, allowing students to work on their language skills during the program. We should also highlight the non-applicability of certain stages for students from particular groups, such as the exemption of indigenous candidates from the written exam.

Moreover, some programs altered their rules for the distribution of scholarships - generally tied to candidates' classification in the admission process. They established that affirmative action students would be prioritized to receive scholarships, which could also become an incentive to a more considerable inflow of a diverse pool of students. Interviewee $\mathrm{H}$ noted that the program "takes into account the student who entered through the vacancy reservation system to try to provide him with a scholarship in order to guarantee his/her permanence."

\subsection{Cases of displacement}

In admission processes, displacement happens in cases in which traditional admission is modified mostly or completely in order to accommodate to the obstacles faced by certain groups, such as the indigenous. In other words, this means not merely reserving seats for specific groups, but also changing almost all the admission criteria and stages to make the process more inclusive.

Programs that altered more than $70 \%$ of the admission criteria in favor of certain groups were considered cases of displacement; that is, those that present a degree of change equal or superior to 0.7. Graph 2 (above) shows that only 3.6\% of the programs have degrees of change greater than 0.7 , which corresponds to only five programs.

\footnotetext{
${ }^{14}$ As in the case of Interviewee HS's program.
} 
Among these five programs, four programs are in the field of Anthropology. According to the documents and proposals analyzed, the diffusion of these policies in the field is linked to disseminating innovation within academic networks. However, this wasn't limited to imitation, as many Anthropology programs adopted different practices and criteria.

The graduate program in Social Anthropology from the University of São Paulo, for instance, presents the highest degree of change: 0.889 . The program wholly altered their admissions processes after extensive internal discussions of the process. The resolution approved by the program reserves a percentage of seats for blacks, browns, and people with disabilities and creates additional reserved seats for indigenous people ${ }^{15}$. The program has two selection processes regulated by different guides, being one exclusive for indigenous candidates. Furthermore, applicants - whether or not they opt for affirmative action - have an extended deadline to prove proficiency in foreign languages. Candidates take exams to attest competence in a foreign language before applying to take their qualifying exams, which usually happens in the second year.

The PPGAS-MN/UFRJ program, with a degree of change of 0.7 , became a reference when they approved affirmative action. The program created the policy to respond to graduate students' complaints about the lack of blacks and indigenous students in their cohorts. The proposal ${ }^{16}$ was presented in 2007, underwent several revisions, and was finally approved by the collegiate board in $2012^{17}$. This is an example in which the motion for modifying the admissions process met strong internal resistance, resulting in a long discussion process before being approved (Venturini, 2017). The resolution approved in 2012 established that the program would offer two types of affirmative action (Venturini, 2017). First, a percentage of seats (minimum of $20 \%$ a year) are reserved for black and brown candidates and those who opted for affirmative action would have a lower minimum score $\left(5\right.$ points $\left.{ }^{18}\right)$ in all stages. Secondly, additional seats are reserved for indigenous people, who go through a modified admission's process.

\section{WHAT EXPLAINS EACH TYPE OF CHANGE?}

The data indicate that most graduate programs have gone through change processes classified as layering and that there are only a few cases of displacement. But why?

The main factor contributing to the modification of the admission criteria is the program's field of knowledge. The data shows that graduate programs in Human Sciences have made the most significant changes. Table 1 illustrates that all programs that presented a degree of change of 0.6 or higher are within this field. Interviewee M remarked: "there was resistance, but [...] the humanities - where people are more open to these concerns - is where it all started."

\footnotetext{
${ }_{15}$ Normative Resolution 01/2017. Retrieved from http://ppgas.fflch.usp.br/resolucao-normativa-de-adocao-e-regulamentacao-dapolitica-de-acoes-afirmativas-do-ppgasusp

${ }^{16}$ Two proposals presented to the program in 2007 and 2012 have been made available to the author. For more information on this process, please see: Venturini (2017).

${ }^{17}$ Program's Resolution n. 6/2012. Retrieved from https://ppgas.museunacional.ufrj.br/uploads/7/0/8/7/70878475/resolucao_6_2012_ acao_afirmativa.pdf

${ }^{18}$ The minimum score for applicants who are not opting for affirmative action is 7 . The scores vary from 0 to 10 (highest).
} 

ACCORDING TO THE DEGREE OF CHANGE AND FIELD OF KNOWLEDGE ( $\mathrm{N}=137)$

\begin{tabular}{|c|c|c|c|c|c|c|c|c|}
\hline & $\begin{array}{c}0.100 \text { to } \\
0.199\end{array}$ & $\begin{array}{c}0.200 \text { to } \\
0.299\end{array}$ & $\begin{array}{c}0.300 \text { to } \\
0.399\end{array}$ & $\begin{array}{c}0.400 \text { to } \\
0.499\end{array}$ & $\begin{array}{c}0.500 \text { to } \\
0.599\end{array}$ & $\begin{array}{c}0.600 \text { to } \\
0.699\end{array}$ & $\begin{array}{c}0.700 \text { to } \\
0.799\end{array}$ & $\begin{array}{c}0.800 \text { to } \\
0.899\end{array}$ \\
\hline Agricultural Sciences & $5.6 \%$ & $0.0 \%$ & $0.0 \%$ & $0.0 \%$ & $0.0 \%$ & $0.0 \%$ & $0.0 \%$ & $0.0 \%$ \\
\hline Biological Sciences & $3.3 \%$ & $4.3 \%$ & $0.0 \%$ & $0.0 \%$ & $0.0 \%$ & $0.0 \%$ & $0.0 \%$ & $0.0 \%$ \\
\hline Health Sciences & $4.4 \%$ & $0.0 \%$ & $0.0 \%$ & $0.0 \%$ & $0.0 \%$ & $0.0 \%$ & $0.0 \%$ & $0.0 \%$ \\
\hline Exact and Earth Sciences & $1.1 \%$ & $4.3 \%$ & $0.0 \%$ & $0.0 \%$ & $0.0 \%$ & $0.0 \%$ & $0.0 \%$ & $0.0 \%$ \\
\hline Human Sciences & $37.8 \%$ & $60.9 \%$ & $44.4 \%$ & $100.0 \%$ & $66.7 \%$ & $100.0 \%$ & $100.0 \%$ & $100.0 \%$ \\
\hline Applied Social Sciences & $26.7 \%$ & $8.7 \%$ & $33.3 \%$ & $0.0 \%$ & $0.0 \%$ & $0.0 \%$ & $0.0 \%$ & $0.0 \%$ \\
\hline Linguistics, Literature and Arts & $7.8 \%$ & $13.0 \%$ & $11.1 \%$ & $0.0 \%$ & $33.3 \%$ & $0.0 \%$ & $0.0 \%$ & $0.0 \%$ \\
\hline Multidisciplinary & $13.3 \%$ & $8.7 \%$ & $11.1 \%$ & $0.0 \%$ & $0.0 \%$ & $0.0 \%$ & $0.0 \%$ & $0.0 \%$ \\
\hline
\end{tabular}

Source: Elaborated by the author.

The predominance of Human Sciences seems to be related to its proximity to studies of inequality. During the interviews, it was clear that people in the Human Sciences, Applied Social Sciences, and Linguistics, Literature, and Arts fields had much more information about the obstacles that certain groups face in their journey to access higher education. This information would allow greater recognition of the problem in graduate programs and the need to do something about it.

Furthermore, the programs in these fields saw the admission of students from various backgrounds as beneficial to the improvement of scientific research. The Interviewees suggested that diversity was essential to enable new problems and methodological approaches. Interviewee HS noted that these groups "bring us an experience that many who have been at the university for a long time have forgotten." Interviewee SA also mentioned, "the importance of oxygenating the debate itself in reality through thematic diversity. You can bring new themes, themes that are in society. The University is not very permeable to these themes."

For Interviewee Bio, the fact that the program has 'a solid regional 'vocation,' and regional insertion is one of the strengths of the program, so for us, it would be interesting to know that we were able to fulfill this social role also in graduate school." Interviewee LLA noted that "the program wants an insertion on the margins of society" and for an arts course that deals with a "symbolic world," it is crucial to have "a somewhat heterogeneous, perhaps eclectic, composition of the student body."

The data also corroborates the understanding that the programs that changed the admission processes more significantly were the ones in Anthropology, whose significant changes have been in 
favor of indigenous applicants. It could be argued that the programs' proximity to these ethnic groups allowed for the consideration of their specificities in policy design. In the case of the program in Social Anthropology at USP, for instance, the affirmative action proposa ${ }^{19}$ presented to the program highlights the importance of considering the differences in indigenous schooling and the benefits that their presence could bring to the field. Interviewee $\mathrm{M}$ also mentioned the benefits that indigenous students could bring to the programs:

[...] it would be important not only for the indigenous to enter but also for knowledge to enter. People want to study indigenous and make indigenous research objects, but they do not always see them as subjects. So, we raise an epistemological question of how the subject-object relationship is thought in the production of scientific knowledge.

Many interviewees also indicated that the inclusion of specific groups and changes in the admission processes had been emphasized by members of research groups. Interviewee $\mathrm{H}$ pointed out that the program has a solid line of research on gender and sexuality for almost 30 years, and a doctoral student highlighted the barriers faced by transgender students to access the graduate system. A similar situation occurred in the program of Interviewee LLA, in which "it was a professor who raised this issue" due to his long history and participation in the black movement. Interviewee HS also highlighted the proximity of the field (health) to matters linked to inequalities.

Some interviewees also mentioned too much resistance to structural modifications due to the importance of academic merit and excellence. They opted to approve quotas or create additional seats while maintaining existing rules intact to discuss more substantial changes in the future. Interviewee LLA, for example, mentioned that the program only reserved seats and chose not to change the selection process because "there was a consensus in the program that, in the selection process, academic merit must also be weighed and prevail."

\section{FINAL CONSIDERATIONS}

The main objective of this paper was to fill this gap and explain how the creation of affirmative policies resulted in the modification of the traditional selection process carried out by graduate programs and to identify the different types of change. The process of formulating affirmative policies and change in graduate admission provides important inputs on institutional dynamics and processes of change in favor of reducing inequalities.

The data presented in the paper provide a first look at a topic not yet analyzed in the specialized literature. The institutional change approach is not traditional in affirmative action research. The paper presents an interdisciplinary approach, as it connects the political science literature regarding inequalities, public policies and race relations. The institutional change typology allowed us to verify that most graduate programs created affirmative action (quotas or additional reserved seats) but did not significantly change their admission processes. Most programs have undergone layering processes,

\footnotetext{
${ }^{19}$ The proposal has been published in an Anthropology journal. See Marques et al. (2017).
} 
with few cases of displacement and almost complete modifications of selection processes due to the barriers faced by certain groups.

The predominance of layering cases points to a tendency for continuity and maintenance of the same criteria and selection procedures, which are seen as sufficient to achieve the actors' desired results and maintain resources allocated to the programs. Uncertainty regarding the impact that affirmative action could have on the Capes score also seems to have contributed to more layering cases. For some programs, in the face of an issue that encounters resistance among faculty, the sole adoption of quotas proved to be the best strategy available, allowing the reservation of places to be approved, so that the possibility of more structural modifications could be considered in the future.

The predilection for low degrees of change and layering can be explained by the strong resistance to making more substantial changes in the admission processes due to the importance that programs and faculty place on academic merit. However, for graduate education to fulfill its social role and be more representative of society, it is fundamental that the conception of meritocracy adopted by faculty and selection committees be more sensitive to inequalities.

In this way, graduate courses' selection processes need to take into account the barriers faced by disadvantaged groups for enrollment in the admission processes and throughout these processes, as well as the achievements of these individuals in the context of the opportunities they have had throughout their lives.

Finally, further studies are needed to analyze the internal dynamics and aspects that represent obstacles or institutional impulses for more substantial changes in the selection processes and differences in the intensity of adherence to policies and types of change in the various areas of knowledge and regions of the country. For this, it is imperative that data from public higher education, including graduate education, be made available to the public and the research community, in order to give us a realistic view of the impact of affirmative action policies and the changes they generate. 


\section{REFERENCES}

Aberbach, J.D., \& Rockman, B. A. (2002). Conducting and Coding Elite Interviews. Political Science \& Politics, 35(4), 673-676. Retrieved from https://doi. org/10.1017/S1049096502001142

Arruti, J. M. (2008). Quilombos. In O. A. Pinho, \& L. Sansone (Eds.), Raça: novas perspectivas antropológicas (2a ed. rev, pp. 315-350). Salvador, BA: EDUFBA.

Artes, A. (2016). Desigualdades de cor/raça e sexo entre pessoas que frequentam e titulados na pósgraduação brasileira. In A. Artes, S. Unbehaum, \& V. Silverio (Eds.), Ações Afirmativas no Brasil: reflexõese desafios para a pós-graduação (pp. 19-59). São Paulo, SP: Editora Cortez.

Associação Brasileira de Antropologia. (1994). Documento do grupo de trabalho sobre comunidades negras rurais. Retrieved from https://acervo. socioambiental.org/acervo/documentos/ documento-do-grupo-de-trabalho-sobrecomunidades-negras-rurais

Baumgartner, F., \& Jones, B. (1993). Agendas and instability in American politics. Chicago, IL: University of Chicago Press.

Capoccia, G. (2015). Critical junctures and institutional change. In J. Mahoney, \& K. Thelen (Eds.), Advances in comparative-historical analysis (pp. 147-179). New York, NY: Cambridge University Press.

Capoccia, G., \& Kelemen, D. (2007). The Study of Critical Junctures: theory, narrative, and counterfactuals in historical institutionalism. World Politics, 59(3), 341-369. Retrieved from https://doi. org/10.1017/S0043887100020852

Diniz, J. A. F., Filho, Fioravanti, M. C. S., Mello, L., Fredrigo, F. S., Paula, M. H., Dias, L. O. ... Oliveira, D. D. (2016). Cotas étnico-raciais na pós-graduação: a experiência da Universidade Federal de Goiás. In A. Artes, S. Unbehaum, \& V. R. Silvério (Eds.), Ações Afirmativas no Brasil: reflexões e desafios para a pós-graduação (pp. 183-212). São Paulo, SP: Cortez Editora.

Durham, E. R. (1998). As universidades públicas e a pesquisa no Brasil (Documento de trabalho, 9/98). São Paulo, SP: Núcleo de Pesquisas sobre Ensino Superior da Universidade de São Paulo.
Retrieved from http://nupps.usp.br/downloads/ docs/dt9809.pdf

Feres, J., Jr., Campos, L. A., Daflon, V. T., \& Venturini, A. C. (2018). Ação afirmativa: conceito, história e debates. Rio de Janeiro, RJ: EdUERJ. Retrieved from https://www.eduerj.com/eng/?product=acaoafirmativa-conceito-historia-e-debates

Fiori, A. L., Assênsio, C. B., Andrade, F., Teixeira, J. M., Patriarca, L., \& dal Bo, T. L. (2017). O tempo e o vento: notas sobre a arte de burocratizar políticas de cotas na USP. Revista de Antropologia, 60(1), 55-83. Retrieved from https://doi.org/10.11606/2179-0892. ra.2017.132101

Goldman, M., \& Banaggia, G. (2017). A política da má vontade na implantação das cotas étnico-raciais. Revista de Antropologia, 60(1), 16-34. Retrieved from https://doi.org/10.11606/2179-0892.ra.2017.132062

Goldstein, K. (2002). Getting in the Door: Sampling and Completing Elite Interviews. Political Science \& Politics, 35(04), 669-672. Retrieved from https://doi. org/10.1017/S1049096502001130

Gurin, P., Dey, E., Hurtado, S., \& Gurin, G. (2002). Diversity and Higher Education: Theory and Impact on Educational Outcomes. Harvard Educational Review, 72(3), 330-367. Retrieved from https://doi. org/10.17763/haer.72.3.01151786u134n051

Hacker, J. S., Pierson, P., \& Thelen, K. (2015). Drift and conversion: hidden faces of institutional change. In J. Mahoney, \& K. Thelen (Eds.), Advances in comparative-historical analysis (pp. 180-208). New York, NY: Cambridge University Press.

Hall, P. A. (1986). Governing the economy: the politics of state intervention in Britain and France. Oxford, UK: Blackwell.

Harvey, W. S. (2011). Strategies for conducting elite interviews. Qualitative Research, 11(4), 431-441. Retrieved from https://doi. org/10.1177/1468794111404329

Hochschild, J. L. (2005). Conducting Intensive Interviews and Elite Interviews. In M. Lamont, \& P. White (Eds.), Workshop on Interdisciplinary Standards for Systematic Qualitative Research (pp. 124-127). Alexandria, VA: National Science Foundation. Retrieved from https://www.nsf.gov/ sbe/ses/soc/ISSQR_workshop_rpt.pdf 
Jenkins, L. D., \& Moses, M. S. (2014). Affirmative Action Matters: Creating opportunities for students around the world. Abingdon, UK: Taylor \& Francis.

Kapiszewski, D. (2015). Field research in political science: practices and principles. Cambridge, UK: Cambridge University Press.

Katznelson, I. (2003). Periodization and preferences: reflections on purposive action in comparativehistorical social science. In J. Mahoney, \& D. Rueschemeyer (Eds.), Comparative historical analysis in the social sciences (pp. 270-303). Cambridge, UK: Cambridge University Press.

Kennedy, R. (2015). For discrimination: race, affirmative action, and the law. New York, NY: Vintage Books.

Kurasaki, K. S. (2000). Intercoder Reliability for Validating Conclusions Drawn from Open-Ended Interview Data. Field Methods, 12(3), 179-194. Retrieved from https://doi. org/10.1177/1525822X0001200301

Leech, B. L. (2002). Asking Questions: Techniques for Semistructured Interviews. PS: Political Science and Politics, 35(4), 665-668. Retrieved from https:// doi.org/10.1017/S1049096502001129

Lynch, J. (2013). Aligning Sampling Strategies with Analytic Goals. In L. Mosley (Ed.), Interview Research in Political Science (pp. 31-44). London, UK: Cornell University Press.

Mahoney, J. (2000). Path dependence in historical sociology. Theory and Society, 29(4), 507-548. Retrieved from https://doi.org/10.1023/A:1007113830879

Mahoney, J., \& Thelen, K. (2010). A theory of gradual institutional change. In J. Mahoney \& K. Thelen (Eds.), Explaining Institutional Change (pp. 1-37). Cambridge, UK: Cambridge University Press.

Marques, A. C. R. D., Fiori, A. L., Assênsio, C. B., Andrade, F., Teixeira, J. M., Patriarca, L. ... Dal' Bó, T. L. (2017). A proposta de cotas e ações afirmativas do Programa de PósGraduação em Antropologia Social da Universidade de São Paulo: do tédio à melodia. Cadernos de Campo (São Paulo), 25(25), 46-55. Retrieved from https://doi.org/10.11606/ issn.2316-9133.v25i25p46-55

Mosley, L. (2013). Interview Research in Political Science. London, UK: Cornell University Press.
Moura, C. (1972). Rebelióes da senzala: quilombos, insurreições, guerrilhas. São Paulo, SP: Conquista.

Nascimento, A. (1980). O quilombismo. Petrópolis, RJ: Vozes.

Nature, E. (2014). Diversity challenge. Nature, 513, 279. Retrieved from https://doi.org/10.1038/513279a

Pereira, A. C. (2017). Preto, gay e do Norte: ações afirmativas na pele. Revista de Antropologia, 60(1),3546. Retrieved from https://doi.org/10.11606/21790892.ra.2017.132065

Pierson, P. (2004). Politics in time: history, institutions, and social analysis. Princeton, NJ: Princeton University Press.

Posselt, J. R. (2014). Toward Inclusive Excellence in Graduate Education: Constructing Merit and Diversity in PhD Admissions. American Journal of Education, 120(4), 481-514. Retrieved from https:// doi.org/10.1086/676910

Posselt, J. R. (2016). Inside graduate admissions: merit, diversity, and faculty gatekeeping. Merit, diversity, and faculty gatekeeping. Cambridge, MA: Harvard University Press.

Ribeiro, C. A. C., \& Schlegel, R. (2015). Estratificação horizontal da educação superior no Brasil: 1960 a 2010. In M. T. S. Arretche (Ed.), Trajetórias das desigualdades: como o Brasil mudou nos últimos cinquenta anos. São Paulo, SP: Editora UNESP.

Rosemberg, F. (2013). Ação afirmativa na pósgraduação: o programa internacional de bolsas da Fundação Ford na Fundação Carlos Chagas (Textos FCC, 36). São Paulo, SP: FCC/SEP.

Sabbagh, D. (2007). Equality and transparency: a strategic perspective on affirmative action in American law. New York, NY: Palgrave Macmillan.

Santos, J. T. (2010). Pós-graduação em Direito e Ações Afirmativas no Brasil: uma experiência induzida. Revista Pós Ciências Sociais, 7(14), 155-172. Retrieved from http://www.periodicoseletronicos. ufma.br/index.php/rpcsoc/article/view/570

Senkevics, A. S., \& Mello, U. M. (2019). $\mathrm{O}$ perfil discente das universidades federais mudou pós-lei de cotas? Cadernos de Pesquisa, 49(172), 184-208. Retrieved from https://doi. org/10.1590/198053145980 
Silva, G. M. D. (2006). Ações afirmativas no Brasil e na África do Sul. Tempo Social, 18(2), 131-165. Retrieved from https://doi.org/10.1590/S010320702006000200007

Streeck, W., \& Thelen, K. A. (2005). Beyond continuity: institutional change in advanced political economies. Oxford, UK: Oxford University Press.

Thelen, K. (2003). How institutions evolve: insights from comparative-historical analysis. In J. Mahoney, \& D. Rueschemeyer (Eds.), Comparative historical analysis in the social sciences (pp. 208-240). Cambridge, UK: Cambridge University Press.

Thelen, K. (2004). How institutions evolve: The political economy of skills in Germany, Britain, the United States, and Japan. Cambridge, UK: Cambridge University Press.

Thelen, K. (2009). Institutional change in advanced political economies: First annual lecture of the bjir.
British Journal of Industrial Relations, 47(3), 471498. Retrieved from https://doi.org/10.1111/j.14678543.2009.00746.x

Venturini, A. C. (2017). Formulação e implementação da ação afirmativa para pósgraduação do Museu Nacional. Cadernos de Pesquisa, 47(166), 1292-1313. Retrieved from https://doi.org/10.1590/198053144438

Venturini, A. C. (2019). Ação afirmativa na pósgraduação: os desafios da expansão de uma política de inclusão (Doctoral Dissertation). Universidade do Estado do Rio de Janeiro, Rio de Janeiro, RJ. Retrieved from http://www.bdtd.uerj.br/handle/1/12384

Venturini, A. C., \& Feres, J., Jr. (2020). Affirmative action policy in graduate studies: The case of public universities. Cadernos de Pesquisa, 50(177), 882-909. Retrieved from https://doi. org/10.1590/198053147491

\section{Anna Carolina Venturini}

https://orcid.org/0000-0001-8370-5476

Ph.D. in Political Science from the Institute of Social and Political Studies (IESP) of the State University of Rio de Janeiro (UERJ); Postdoctoral fellow at the Brazilian Center of Analysis and Planning - CEBRAP's International Interdisciplinary Postdoctoral Program (IPP).E-mail: anna.venturini@cebrap.org.br 